Politisch engagiert, jedoch ohne die für eine politikwissenschaftliche Argumentation notwendige Distanz zum Gegenstand zu verlieren, gibt dieses zweibändige Werk von Carrizosa und Vial einen umfassenden Einblik in die staatsrechtliche Entwicklung und in die aktuelle staatspolitische Diskussion der südlichsten Länder Lateinamerikas. Vor allem dem zweiten Band gelingt es, mit der durch thematische Beschränkung und Beispielhaftigkeit empirisch fundierten Analyse die konkreten Probleme der politischen Umbruchsituation und ihre Zusammenhänge kenntnisreich und in größter Anschaulichkeit zu vermitteln. Dazu trägt die unprätentiöse, gut verständliche Sprache der Bücher bei, insbesondere für diejenigen, die mit der Materie nicht vertraut sind. Den an streng wissenschaftliche Bücher gewöhnten Leser mag die Art und Wahl der Hervorhebungen im Text etwas befremden oder der sparsame Umgang mit Fußnoten zu wünschen übrig lassen. Hierbei ist jedoch der generelle Mangel an einschlägiger Literatur zu bedenken. Schon in Anbetracht der Tatsache, daß es zu dem in diesen zwei Büchern bearbeiteten Thema der Legislativgewalt, v.a. in Paraguay, keine weitere Literatur gibt, leistet das Werk einen unentbehrlichen Beitrag zur verfassungsrechtlichen Forschung. Nur (leider?) in spanischer Sprache.

Anja Schoeller-Schletter

\title{
Martina Zellmer \\ Die "Enterprise for the Americas Initiative" - Eine neue Entwicklungspolitik der USA gegenüber Lateinamerika?
}

Arnold-Bergstraesser-Institut (Freiburger Beiträge zu Entwicklung und Politik; 15), Freiburg 1994, 145 S., DM 18,--

Auch wenn die von Martina Zellmer vorgelegte Untersuchung bereits im Juli 1992 abgeschlossen wurde und die neuesten Entwicklungen im Zusammenhang mit der nordamerikanischen Freihandelszone NAFTA nicht mehr berücksichtigen konnte, verdient sie doch Beachtung, ist doch gerade der Untertitel bewußt mit einem Fragezeichen versehen worden. Konsequent ist es dann, wenn die Autorin bereits in ihrem Eingangskapitel "aufgrund dieser fast völligen Abwesenheit humanitärer Zielsetzungen bei der Konzeption" den Begriff "Entwicklungspolitik" immer in Anführungszeichen setzt.

Naturgemäß nimmt bei der Studie die Beschreibung verschiedener Phasen der US-Entwicklungspolitik zwischen 1939 und 1989 einen verhältnismäßig großen Platz ein. Obwohl als Beginn der US-Entwicklungspolitik gemeinhin das "Point Four"-Programm von Präsident Truman aus dem Jahr 1949 angesehen wird, haben Washingtons Unterstützungsmaßnahmen für Lateinamerika ab 1939, also seit Beginn des 2. Weltkrieges, die Basis für die Zusammenarbeit geschaffen. Galt es zunächst, das Einsickern nationalsozialistischer Ideen zu verhindern, sollte zukünftig der Kommunismus in der Hemisphäre abgewehrt werden. In 
der Zeit von 1939 bis 1945 flossen gerade einmal 678.000 Dollar in entwicklungspolitische Hilfsprogramme, während gleichzeitig 400 Millionen Dollar zur Sicherung strategisch wichtiger Rohstoffe aufgewendet wurden. Im Zeitraum von 1949 bis 1959 betrug das Verhältnis von Wirtschafts- zu Militärhilfe noch vier zu eins. Ende der 50er Jahre hatte sich diese Relation genau umgekehrt.

Nach der kubanischen Revolution 1959 wurde zunächst ein Wandel in der entwicklungspolitischen Zusammenarbeit angedacht, der die Armutsbekämpfung in den Vordergrund rückte. Dennoch wurde recht bald klar, daß diese "Alliance for Progress" scheitern würde. Denn gleichzeitig initiierte man ein Aufstandsbekämpfungsprogramm, das die Kooperation mit den herrschenden militärischen und wirtschaftlichen Kräften in Lateinamerika notwendig machte. Als Ende der 60er Jahre Kuba für Washington an sicherheitspolitischer Bedeutung verlor, verringerte sich die US-Entwicklungshilfe für Lateinamerika binnen weniger Jahre von 1,1 Milliarden Dollar (1968) auf rund 566 Millionen (1977).

Als Präsident Carter 1977/78 einen Schwenk in der Entwicklungspolitik zumindest verbal einleitete, indem er zunehmend die Einhaltung von Menschenrechten zur Basis der Unterstützung machen wollte, führte dies allenfalls zu einer Reduzierung der Haushaltsmittel. Der Wechsel im Weißen Haus von Carter zu Reagan bewirkte dann in den 80er Jahren auch einen Wechsel hin zu den "Reaganomics" für die Dritte Welt: Freiheit des Marktes, Privatwirtschaft und uneingeschränkter ökonomischer Liberalismus. Ob Reagan mit seiner "Caribbean Basin Initiative" die wirtschaftliche Lage in Mittelamerika, dem "Hinterhof" der USA aus allgemeinen sicherheitspolitischen Erwägungen verbessern oder damit von der zunehmenden Militarisierung des Isthmus zur Bekämpfung kommunistischer Einflüsse ablenken wollte, kann hier nicht geklärt werden. Fest steht nur, daß die vor Carter befürwortete menschenrechtsorientierte Entwicklungshilfepolitik auch theoretische keine Fortsetzung gefunden hat.

Mit dem Ende des Kalten Krieges wurde dann die "Enterprise for the Americas Initiative" formuliert. In Nicaragua hatten die Sandinisten die Präsidentschaftswahlen verloren; eine kommunistische Bedrohung konnte ernsthaft nicht mehr behauptet werden, zumal Kuba auf ein wirtschaftliches Desaster zusteuerte. Sicherheitspolitische Gründe konnten also eine Entwicklungshilfe nicht mehr begründen; zudem zeichneten sich in den USA erhebliche innenpolitische Probleme durch das Haushaltsdefizit ab. Reduktion der Auslandsverschuldung der lateinamerikanischen Staaten, Reformen zum Abbau investitionshemmender Maßnahmen und Errichtung einer Freihandelszone (von Alaska bis Feuerland) - diese drei Komponenten sollen durch die Initiative der "Enterprise" gefördert werden. Von direkter Armutsbekämpfung ist keine Rede mehr; auch sicherheitspolitische Aspekte spielen keine Rolle. Die Reaktion aus den lateinamerikanischen Hauptstädten war gemeinhin sehr positiv, was auch nicht verwundert angesichts der Tatsache, daß mittlerweile fast überall eine neo-liberale Wirtschaftspolitik verfolgt wird, für die diese Konzeption geradezu maßgeschneidert erscheint. Außerdem haben die Staaten der südlichen Hemisphäre auch keine Möglichkeit, sich dieser Politik zu entziehen, da sich Europa und Japan als potentielle 
Konkurrenten der USA in dieser Region auf ihre jeweiligen geographisch näherliegenden Interessengebiete (Osteuropa bzw. Asien) konzentriert haben.

Die "Enterprise" ist also "ausschließlich das Produkt eigennütziger Überlegungen der U.S.A.". Diese Behauptung kann die Autorin durch eine eingehende Analyse untermauern, gestützt auf zahlreiche offizielle und auch unveröffentlichte Quellen sowie eine beachtliche und umfangreiche Literaturauswahl. Auch wenn sie bedauert, wegen fehlender Sprachkenntnisse auf die Verwendung spanischsprachiger Literatur verzichten zu müssen, so tut das dieser Arbeit keinen Abbruch, geht es doch vor allem um die entwicklungspolitischen Leitlinien US-amerikanischer Politik und nicht um deren Rezeption in Lateinamerika. In ihrem Fazit verneint die Autorin die Frage, ob die "Enterprise" eine neue Entwicklungspolitik der USA gegenüber Lateinamerika darstellt. Auch nicht ansatzweise spielten humanitäre Überlegungen eine Rolle, vielmehr seien es ausschließlich wirtschaftliche und politische Gründe. Dieses Programm sei in der Furcht begründet, daß die USA seit dem Ende des Kalten Krieges zunehmend ihre Rolle als Hegemonialmacht in der westlichen Welt einbüßten und nunmehr, quasi als Kompensation, sich wieder verstärkt dem lateinamerikanischen Kontinent zuwenden würden.

Jürgen Saligmann

The University of Sarajevo / World University Service/WUS Austria (eds.)

Manual on Co-operation with the University of Sarajevo

Sarajevo 1996, 383 pp.

This manual does not allow a review, but it deserves attention. The book contains information on the development, structure and present situation of the University of Sarajevo (Part I, pp. 10-62) and a distinct list of needed material, literature and equipment listed seperately for each of the 24 faculties (Part II, pp. 67-382). It is edited by the University of Sarajevo in Bosnia and Herzegovina in cooperation with the Austrian Committee of the World University Service.

Thus the manual serves a special function in the time of the reconstruction of a scientific institution. It describes the status quo of each faculty and each building, it lists the material needed for the coming practical steps of reconstruction and it provides contacts assuring that the material and help offered will not only reach Sarajevo, but the faculty in need.

The details are striking, especially as far as the extent of destruction and the needs of the branches of the university are laid down. However, the manual also explains the historic background of the institution (p. 10-21). Some faculties of the University of Sarajevo, as it is known today, started to work in 1946, although the university itself was not founded until 1949. The original roots reach back through some 600 years of higher education in Bosnia and Herzegovina. And - in spite of extensive destruction of buildings and premises in the war - these roots have not been destroyed until today. The university continued its work through the recent war by organizing courses in small groups and individual exami- 